\title{
(In)tolerance of Diversity and School Governance: Perceptions and Experiences of Parents in Soweto Secondary Schools
}

\section{Patrick Mafora}

\author{
University of South Africa \\ Department of Educational Leadership and Management \\ Email:pmafora@unisa.ac.za
}

Doi: 10.5901/mjss.2013.v4n4p101

\begin{abstract}
A qualitative multi case study on shared decision-making in School Governing Bodies (SGBs) was conducted in five secondary schools in Soweto, South Africa. This article is restricted to the research question: how do parent members of the SGB perceive and experience respect and tolerance of diversity within the SGB. Data were collected through in-depth, semistructured individual and group interviews. Tesch's steps for open coding were followed for data analysis. Findings indicate that parents perceive and experience SGBs as discriminative, divisive, and intolerant of their "otherness". Dimensions of diversity, notably socio-economic background and opinions-held, are used as the basis for suppression and marginalisation. The article argues for the introduction of school-level policies and relevant capacity building initiatives on democracy and social justice issues, as a means of improving the situation.
\end{abstract}

Keywords: deliberative democracy, diversity, tolerance, school leadership, Soweto

\section{Introduction}

The global trend in school governance and administration reform has been a shift towards devolving decision-making power to schools (Karlsson, 2002; Aspin, 1995). Such practice is informed by the view that people closest to teaching and learning are in the best position to make decisions that affect their schools as they have first-hand knowledge of relevant issues (Parker \& Leithwood, 2000; Everett, 1998). Giving more decision-making power and responsibility to parents is believed to culminate in better functioning schools (Harber, 2004; Apple \& Beane, 1999). In line with the global practice and the post-1994 policy developments, South Africa introduced decentralised school governance and democratic shared decision-making through the South African Schools Act, No. 84 of 1996 (RSA,1996). In terms of this Act (hereafter SASA), parents, principals, teachers, support staff, and learners in secondary schools may be elected to School Governing Bodies (SGBs). The overarching goal of SGBs is the democratic transformation of schools and providing a better teaching and learning environment (Shumane 2009; Mahlangu, 2008; Van Wyk, 2004). The prescribed functions of the SGB are centred around policy formulation and oversight on its implementation. These functions include, among others, adopting a constitution and a code of conduct for learners; deciding on the language policy of the school and fees to be charged; overseeing the maintenance and control of school property; and recommending the appointment of teaching and non-teaching staff (RSA, 1996). The execution of these governance tasks should be undergirded by the following core democratic values (Department of Education, 1996);

- Representation of all stakeholder groups;

- Active participation;

- Tolerance;

- Rational discussion; and

- Collective decision-making.

To avoid domination of parents by other stakeholders, the power balance in the SGB gives the greatest say to the parents. They hold a majority through a $50 \%$ plus one member representation (Karlsson, 2002; RSA, 1996) and only a parent-member may serve as SGB chairperson. SASA prescribes that only parents of learners attending a particular school may be elected to its SGB. People who are not parents of learners but are co-opted because of their expertise hold no voting rights (RSA, 1996). The pool of voting parents with expertise in township schools is limited because of their low levels of education which is attributable to imbalances of the past (Shumane, 2009; Mahlangu, 2008). Township 
elites are usually not eligible for election to township SGBs because their children are usually enrolled in former model C schools in suburbs. It is thus not surprising that SGBs in most township schools are deemed to be dysfunctional (Mangena, 2012; Mncube, 2009) or to reflect domination by more educated community members (Van Wky, 2007; Ministerial Review, 2004).

The progress made with regard to the integration and democratisation of decision-making structures in South Africa remains debatable. Invariably, all praise for progress made is qualified or counterbalanced with expressions of some reservations. Parallel to confirmation of some progress being made (MacGillivray \& Golden, 2007; Brown, 2006; Jansen, 2004), findings from recent studies suggest that SGB practices and processes are not entirely democratic (Adams \& Waghid, 2005; Heystek, 2004; Mabovula, 2009; Magadla, 2007; Mncube, 2009). It is commonly held that in spite of the existence of structures for democratic participation, South Africa still has a long way to go to make democratic ideals achievable within educational institutions (Adams \& Waghid, 2005; Jansen, 2004; Karlsson, 2002). This view is shared by other researchers on various grounds. According to Van Wyk (2007), the change to shared decision-making in South African schools failed to take into cognisance the diversity that exists, especially with regard to the management of discriminatory practices. Karlsson (2002) adds that inequalities, social class, race and gender issues that characterised the apartheid education system are still promoted in SGBs. Similarly, Brown and Duku (2008) maintain that SGBs are fraught with an ethos of social domination, rejection and the concomitant tension and psychological stress. These observations suggest that, while the creation of the SGBs as democratic structures is viewed as a success in some quarters, there is doubt regarding the extent to which their processes reflect core democratic values. A disturbing finding in this regard is that, in spite of evidence of undemocratic practices within SGBs, most SGB members tend to deny the existence of competing constituent interests, values and demands (Grant-Lewis \& Naidoo, 2004). One may then ask: how does an SGB that grapples with embracing democracy in terms of its values, processes and procedures pursue democracy and school effectiveness as its legislated mandate? The study reported in this article was conceived of against the backdrop of these concerns regarding the manifestation of democracy within the SGBs. This article is restricted to the research question: how do parent members of the SGB perceive and experience respect and tolerance of diversity within the SGB? Given the diversity between and within the groups represented in SGBs, this study was considered pertinent. It was hoped that addressing this research question could help identify practices and processes that contribute to SGBs being perceived as undemocratic, stifling participation and ineffective.

\section{Literature review}

This study is undergirded by the theories of tolerance of diversity and deliberative democracy. According to Gutmann and Thomson (Paul, Miller \& Paul, 2000) deliberative democracy is the practice of justifying policies and decisions through discussions by free and equal citizens or their representatives. Adams and Waghid (2005) posit that the constitutive principles of deliberative democracy in South Africa are participation, community engagement, rationality, consensus, equality and freedom. That is, it entails people participating in rational decision-making as equals who pursue the common good, not individual preferences. The personal interests and values which individuals initially have, are critically examined, and may be retained or discarded in favour of the common values and interests. The relative merit of values and interest is established through authentic discussions and debates. For deliberative democrats the justification of democracy depends on the process that people establish to participate, to talk and reason over matters until a collective decision is reached (Waghid, 2002).

The common emphasis in these formulations is that the essence of deliberative democracy is active, uninhibited participation in discussions that generate decisions. This also applies in the context of schools. Shields (2004), avers that education that is democratic offers all legitimate stakeholders opportunities to participate. Schools, and their governing bodies, do not automatically qualify as democratic just because they offer participation opportunities. Rather, this depends mainly on the nature of such participation within the broader school climate (Waghid, 2002; Mafora, 2000). Associated literature (Mncube, Harber \& du Plessis, 2011; Adams \& Waghid, 2005; Mafora, 2000; Crocker, 2004; Harber, 1995) suggests a genuinely democratic climate that is facilitative of deliberative discourse is typified by:

- Unwavering commitment of all members to democratic values, principles and procedures;

- Equality of all people on the basis of their human dignity, irrespective of their age, gender, religion and other differences;

- Equal protection of all people against unfair discrimination and suppression;

- The use of rational discussion, not force or threats, to generate views that inform decisions;

- $\quad$ Free expression of opinions in all discussions; 
- Equal treatment of all opinions expressed during discussions, without regard for the personal circumstances of those expressing them;

- The acceptance or rejection of ideas on the basis of their relative worth, not their source; and

- The sacrifice of individual and sectarian interests in pursuit of the common good.

Drawing from Hytten's (2006) view that democratic societies are ideally just, social justice should be a defining feature of democratic SGBs as contemplated by SASA. Socially just schools and their governing bodies should value principles of equality and solidarity, understand and value human rights, recognise the dignity of every human being (Zajda, Majhanovich \& Rust, 2006) and, promote inclusion and equity (Carlise, Jackson and George, 2006). Exclusionary and marginalising practices which are confirmed by school governance research in South Africa (Mabovula, 2009, Mncube, 2009; Van Wyk, 2007; Magadla, 2007; Heystek, 2004) are inexcusable in democratic schools. Such practices result in the SGB as a structure, as well as its processes and relationships being experienced as unjust. In addition to genuine, non-token participation, deliberative democracy requires that the outcome of the decision-making process must also be just. According to Gutmann (Mafora, 2000), decisions which are unjust should be questioned, even if they are made by the majority, because no amount of deliberation can legitimate an unjust decision. Such questioning should also be directed at majority decisions that were made under pressure without deliberation, or merely to avoid an impasse (Adams \& Waghid, 2005). Dissatisfaction with unjust decisions should, however, be presented as reasoned arguments and through democratic channels. Although the free expression of ideas and the pursuit of social justice are ideal, they are not easily attained. It is common for people who do not wield much power to be afraid to openly express their opinions, particularly if such opinions differ markedly from, or are critical of, opinions of the relatively powerful (Mafora, 2000; Blommaert \& Verschueren, 1998).

Deliberative discourse as a defining feature of democracy is inconceivable without tolerance of diversity or "otherness". Tolerance is conceived of as acceptance and appreciation of different cultures, forms of expression and ways of being human that is based on the recognition of human rights and fundamental freedoms (Aspin, 1995; UNESCO, 1995). It requires that people should be respected for who they are without being subjected to any pressure to be or to think like others, even when they constitute a minority. Tolerance implies that non-discrimination should be guaranteed and the varied manifestations of differences between people and within groups e.g. ethnicity, religion, gender, sexual orientation, ability, and other dimensions should be accommodated. In the context of deliberative democracy these differences are not restricted to appearances but emphasis is on the varied perspectives and approaches that members of different groups bring to the organisation (Thomas \& Ely, 2005). Tolerance dictates that the expression of different and conflicting opinions should be considered the norm. Opinions should be accepted or rejected solely because of their substance or lack thereof, not because of who expresses them or other considerations. That is, the organisational climate should protect and promote free expression of opinions by allowing no covert or overt barriers to the expression of opinions, or the manipulation or distortion of such opinions (Mafora, 2000).

Promoting tolerance of diversity in organisations is a challenge because people are not inherently tolerant and learning to be democratic and tolerant is "difficult" (Rukambe, 2009; Scanlon, in Crocker, 2004). In South Africa promoting diversity should, according to Grant (2007), be approached as a social justice matter because it is bound to fail if people's expectations of fairness and equity are not promoted (Grant, 2007). In the case of SGBs this means that all stakeholders must feel that they are valued and treated with dignity during decision-making, and that the process and its outcomes are fair and reflective of their inputs, not just those of the dominant or preferred individuals and groups. Tolerance would in such a case facilitate the open flow of ideas, by minimising the manifestation of negative attitudes and practices like prejudice, stereotypes and discrimination. This would help broaden and deepen deliberative democracy as a device for making fair decisions (Crocker, 2004). To create a welcoming environment that values and celebrates diversity in an organisation requires a foundation of a code of ethics and anti-discrimination policies and practices (Smith, 2011; Valentine \& Fleischman, 2002), and the commitment of exemplary leaders who will oversee their implementation. The SGBs should, therefore, not rely solely on the non-discriminatory provisions of national legislation like SASA, but should have such clauses in the SGB constitution and be seen to uproot discriminatory practices. Tolerance is considered a virtue and a preferred state because discrimination is wrong both morally and legally (Smith, 2011; Thomas \& Ely, 2005). Its other benefits include improved performance and productivity and, a large pool of varying opinions, ideas and experiences (Gutmann, 1996).

According to Akindele, Olaopa and Salam (2009) intolerance obtains when people are not willing to let others act, speak or think differently from themselves. Intolerant people tend to react through coercion, repression, violence and intimidation (Gibson \& Gouws, 2003; Akindele et al, 2009) resulting in pluralism degenerating into tyranny and chaos (Stetson \& Conti, 2005; Avey, 2002, 2001). It is clear from the relative merits of tolerance vis-a-vis intolerance that SGBs should uphold tolerance of diversity given their school effectiveness and democratisation mandates. Intolerance by its 
nature is the antithesis of deliberative democracy as it thrives on self interest and closes the avenues for free, open and reasoned discussions. Immanuel (in Akindele et al, 2009) contends that intolerance inhibits people's ideas, innovation, and creativity as it creates uncertainty regarding how their opinions will be received by others.

\section{Research Methodology}

In order to understand shared decision making in School Governing Bodies from the participants' perspective (McMillan and Schumacher, 2006) a qualitative multi-site case study was undertaken. One of the research questions drawn from this bigger study is the focus of this article, viz: how do parent members of the SGB perceive and experience respect and tolerance of diversity within the SGB?

\subsection{The study context and sample}

Five secondary schools were selected purposefully from Soweto in the Johannesburg West-D12 Education district. The socio-economic milieu of these schools and the daily hardships faced by families were considered possible catalysts for high levels of political consciousness and activism that may influence perceptions about democracy and related social justice issues like tolerance of diversity in schools. Most families in the area have working class low socio-economic backgrounds. In a study of Soweto households Gray et al, (2006) found, among others, that $11 \%$ of children had lost a parent; $44 \%$ of households had at least one sick adult and could not afford school fees for their children or assist them with homework. The majority of schools are considered dysfunctional and as characterized by, among others, corporal punishment for learners, poor discipline from students and teachers, drug and alcohol abuse (Mokonyane, 2011).

Although all members of the SGB participated in the bigger study, this article is restricted to parent members. From each school four parent members of the SGB, including the chairperson, were selected. Chairpersons were purposively sampled because of their leadership position in the SGB. Convenience sampling was used to draw the three parent members. Only those members who could be available for interviews during the day were included in the study. Only one of the five chairpersons was a woman and only two of the fifteen SGB members were men.

\subsection{Data collection}

Parent members participated in the study through homogenous focus group interviews and chairpersons were interviewed separately in one-to-one sessions. One focus group sessions of about 90 minutes was held in each participating school. Individual interviews for principals were held in their offices and each was about 45 minutes long.

\subsection{Data analysis}

Recorded interview data were transcribed verbatim and analysed following Tesch's steps for open coding (Creswell, 2007). This entailed:

- $\quad$ reading all transcript to get a holistic picture;

- reading individual respondents' transcripts to decipher underlying meaning;

- generating lists of topics from transcripts and clustering them according to commonalities into major topics, unique topics and leftovers;

- comparing the list of topics to the data, abbreviating the topics and assigning codes to appropriate segments of the text;

- converting the most descriptive wording for the topics into categories and grouping cognate categories; and

- $\quad$ assembling data that belongs to each category and performing preliminary analysis.

\subsection{Credibility measures}

To enhance the accuracy and credibility of findings, the following measures were adopted (Conrad \& Serlin, 2006; Saunders, et al, 2000):

- I took an objective stance and did not bring personal perspectives into the data or its analysis;

- Prior to finalizing findings, the tentative interpretation of data was referred to some respondents to clarify uncertainties and verify accuracy and plausibility of findings; and 
- Data from the different focus groups were compared to my field notes and themes from literature study.

\subsection{Ethical considerations}

Before commencing with the study, permission was obtained from the Gauteng Provincial Department of Education and principals of participating schools. Participants were informed that their involvement was voluntary and that they could withdraw from the study if a need arises. They were also assured anonymity and confidentiality. The interviews were conducted in a non-threatening environment and were tape-recorded with the express permission of the respondents.

\section{Findings and discussion}

Findings suggest that while the majority of the parent members perceive the SGB as beset by intolerance, none of the SGB chairpersons share this view. This denial is consistent with other findings (Grant-Lewis \& Naidoo, 2004) and is attributable to attempts by SGB chairpersons to hide their failure to create a democratic SGB environment. A detailed discussion of these findings is outlined under the following three themes which are discussed next, misconceptions about shared decision-making, unequal power relations and, systemic barriers to intolerance:

\subsection{Misconceptions about shared decision-making}

Interview data suggests that a minority of parent members of SGBs have perceptions of intolerance that emanate from their misunderstanding of the principles that undergird shared decision-making. These misconceptions affect their participation in, and satisfaction with, the decision-making process (Smit \& Oosthuizen, 2011). It culminates in their being intolerant of others. This is consistent with the view that perception of justice become justice (Hoy and Tarter, 2004). The same holds true for injustice. Findings reveal that a minority of parents want the power and status which they bring from their social life outside the SGB to give them more say than other SGB members. Others incorrectly think it is because of their lack of power and status that their views are "always" ignored [emphasis mine]. When their views and actions are questioned through reasoned arguments, they claim to be targets of intolerance and marginalisation. An informative comment from one parent was:

At home I am a father and a parent and I am not equal to children. Why here in the SGB? Learners are just children and cannot speak to me like they want. This equality thing is wrong if it takes away my culture of being the head. We can work together but not be equal to women and children...

Similarly, two parents from "School A" maintained that they were justified to frog-march another parent SGB member out of a meeting and threaten him with violence because he "disrespected the principal" by questioning his reported maladministration. Clearly it is their reported conduct, not that of the expelled parent, that flouts the principles of free participation and rational discourse (Adams \& Waghid, 2005; Harber, 1995). They, however, perceive themselves and the principal as victims of intolerance. They claim other SGB members disrespect the principal and want to wrestle power from him because he is from their minority language group. Some parents unashamedly conceded to showing their loyalty to the principal by supporting whatever he proposes even when they do not understand the issue at stake. A point of concern is that, their unfounded perception of intolerance culminates in real intolerance of others and its associated violence and intimidation (Akindele et al, 2009; Gibson \& Gouws, 2003).

Consistent with other findings (Ntshele, 2004; Adams \& Waghid, 2005) the majority of parents reported that it was common for SGB chairpersons and principals to manipulate discussions towards decisions they made together ahead of the formal meetings. Alternatively, the chairpersons defer matters to principals without attempting to engage SGB members in discussions and eliciting alternative opinions. That is, the SGB chairpersons reportedly rush to "seek the principal's guidance and advice" or to "divide the house and vote on the matter". Those parents, who seek to discuss such matters further are deemed time-wasters and are harshly scolded. This effectively silences them and removes their influence from decisions. As found by Adams \& Waghid (2005); Van Wyk (2004) and Ntshele (2004) the majority of parents also reported instances where SGB joint-decisions were simply not implemented by the principals. This flouts the democratic values of tolerance, participation, and joint decisions-making, and it effectively silences different voices and amounts to marginalisation (Crozier, 2000). The irony is that, as found in other studies, SGB chairpersons tend to ignore such malpractice (Grant-Lewis and Naidoo, 2004) permitting pluralism to generate into tyranny and chaos (Stetson \& Conti, 2005) and intolerance begetting intolerance. 


\subsection{Unequal power relations}

Consistent with other findings (Van Wyk, 2007; Adams \& Waghid, 2005; Ministerial Review, 2004) the majority of parents reported that their principals lead and dominate discussions in SGB meetings. This is facilitated by parents' limited knowledge and competence, and their readiness to defer to the authority of principals. A common sentiment from all surveyed parents was that principals tend to form coalitions of convenience with other SGB members perceived to be knowledgeable or influential. Only members of such cliques participate freely and they become the principals' support base for handling dissent and excluding others from meaningful decision-making.

Parents also form their cliques within SGBs on the basis of friendship, language group, zone of residence, gender and other dimensions. During meetings members of cliques reportedly support each other and oppose the rest, and their views hold sway not necessarily because they are more rational or plausible (Adams and Waghid, 2005) but because of who holds them. The majority of respondents reported that when matters are put to a vote, which is invariably by show of hands, parent members tend to vote for the principals' presumed preferred option, not what they truly believe in because they "do not want to be seen to be against the principal". This is consistent with the view that expert and referent power tends to elicit compliance instead of resistance (Graham, in Johnson \& Scollay, 2001). Besides, during SGB meetings it reportedly takes just a hostile stare from inner-circle parents to intimidate others to change their vote.

Findings point to the majority of parent members perceiving themselves as caught up in the intolerance between principals and teachers in the SGB. Reportedly, teachers are never in the principals' inner circle as they usually question the role of principals in the SGB and try to lobby the support of parents. Principals, on the other hand are not comfortable to engage teachers in debates and rely on the authority and ignorance of SGB chairpersons to silence them. The latter invariably become dictatorial or "hand over" to the principals because they are not familiar with meeting procedures (Ndlazi, 1999). In meetings vocal teachers and those parents who are believed to support them are labeled troublemakers and rarely get their views listened to or supported by the inner-circle parents. Although teachers seek the support of parents to challenge principals' stranglehold of power in SGBs, they are also critical of the participation of parents in SGB decision-making. Consistent with Crozier's (2000) finding a majority of parents expressed a concern that teachers only see in them older versions of the problems they encounter from their children. Hence, they disregard their contribution (Ndlazi, 1999). One parent remarked:

How can we participate equally with teachers when all they want is to scold us for our children's misbehavior in school? They do not see parents in us... like our children we must listen to them all the time, which is not why we are in the SGB...

The irony is that, in SGB power politics intolerance and marginalisation are meted out to those with and without knowledge and competence alike, and those who are victims of intolerance are also perpetrators thereof. This is consistent with the observation that because of different voices within SGBs each representative grouping wants to enhance their own interest, which could be at the expense of another group's interests (Adams \& Waghid, 2005).

\subsection{Systematic barriers to tolerance}

The majority of respondents expressed a concern that it is only the personal circumstances of the dominant groups that are considered when logistics for SGB meetings like times, language and procedures are decided. This militates against broad-based participation because parents who are late or absent from meetings that are scheduled at inopportune times are unable to influence decisions that are made. Similarly, it defeats the equal participation requirement if they are present but fail to follow proceedings because of the barriers of language and formal meeting procedures (Mncube, 2009). In all the schools surveyed meeting documents are written in English and proceedings are conducted in English and a supplementary African language understood by the majority of parents. One parent pointed out that, "it is not translation from English into the other languages but a mixture which does not suit everybody and is at times confusing". All parents are erroneously assumed to have a working knowledge of English or "the mixture", and to make sense of meeting documents like agendas, minutes and budgets. This is exacerbated by the failure of SGBs to provide the requisite training to their members (Mncube, 2009; Adams and Waghid, 2005; Van Wyk, 2004) and is viewed by the majority of surveyed parents as a deliberate ploy to exclude them from shared decision making by taking advantage of their circumstances. Training for SGBs is reportedly provided by Education District officials according to their time and content schedules, not the specific needs of the parents as influenced by their unique and varied backgrounds. A noteworthy comment from a "School D" parent in her second term as SGB member was: 
First you know nothing when you join the SGB. If you speak and say wrong things, nobody will listen to you again. People shake their heads before you speak, or their looks say 'shut up'. [It] is worse when your English is not Ok. But again, when you try to speak your language then someone will say they do not understand you... You get training after many months in the SGB and it is not always at the right time or what you want...

The analysis of data reveals that it is only two respondents who attribute their perceived intolerance in the surveyed schools to the absence of a policy framework that enjoins SGB members to be tolerant. This minority view does not suggest that this policy framework is not significant. Rather, it points to the limited understanding of what could help entrench democracy and associated values in the SGBs among parent members. A comment from one of the two parents was:

Our SGB constitution does not say it is wrong to be funny to others, or to prevent others from speaking... nothing happens to people who do funny things in meetings and laugh and criticize others because no constitution says it is wrong

\section{Conclusion}

This study has confirmed the view that democratic policy for regulating school governance in South Africa exists but this is not necessarily implemented (Jansen, 2004; Adams \& Waghid, 2005). The study also established that there is no common understanding of, and commitment to, democratic principles among SGB members. While parent members of the SGB perceive themselves as victims of intolerance and outline its manifestation within SGBs, they also admit to engaging in practices that amount to intolerance of others on the basis of age, views held, social class and gender. Whether real or imagined, perceptions of intolerance influence those who perceive themselves as its victims to feel marginalised and not valued. They either withdraw from the shared decision-making process, or seek to consolidate their position by becoming intolerant of others.

It is the view of this study that intolerance and other undemocratic attitudes and practices can be unlearnt and discarded. In addition to the usual capacity building regarding the roles and responsibilities of the SGB, they should be trained on democratic governance, shared decision-making, meeting procedures and, around issues of diversity. Education for democratic citizenship should be extended to all community members (Mafora, 2012; Parry \& Moran, in Smit \& Oosthuizen, 2011). This may help enhance SGB members' assertiveness and awareness of their rights and fundamental freedoms. It may also sensitise them to embrace democracy as a way of being. Democratisation requires that education should be the means of inculcating knowledge, values and attitudes into democratic practice (Aspin, 1995). School-level policy frameworks that inform governance practice like the SGB constitution should specifically address the implementation of deliberative democracy and associated values like tolerance. As an accountability measure each SGB must have an enforced code of ethics to give effect to democratic principles like the advancement of diversity, equity and human dignity.

\section{References}

Adams, F. \& Waghid, Y. (2005). In defence of deliberative democracy: challenging less democratic school governing body practices. South African Journal of Education, 25(1), 25-33.

Akindele, S.T., Olaopa, O.R. \& Salam, N.F. (2009). Political intolerance as a clog in the wheel of Democratic governance: The way forward. African Journal of Political Science and International Relations, 3(8), 365-379.

Apple, M. \& Beane J. 1999. The case for democratic schools. In: Apple M \& Beane J. Democratic schools: Lessons from the chalk face. Buckingham: Open University Press.

Aspin, D.N. (1995). The conception of democracy: A philosophy for democratic education. In: Chapman, J.D., Froumin I.D. \& Aspin D.N. (Eds). Creating and managing the democratic school. London: Falmer.

Avery, P.G. (2002). Political tolerance, democracy and adolescents, In: Parker W. (Ed.). Education in democracy: contexts, curricular, assessments. Greenwich: Information Age Publishing.

Avery, P.G. (2001). Developing political tolerance. ERIC Digest, ED 458186.

Blommaert, J. \& Verschueren, J. (1998). Debating diversity. London: Routledge.

Brown, K. (2006). "New" educational injustices in the "new" South Africa. A call for justice in the form of vertical equity. Journal of Educational Administration, 44(5), 509-519.

Brown, B. \& Duku, N. (2008). Negotiated identities: Dynamics in parents' participation in school governance in rural Eastern Cape schools and implications for school leadership. South African Journal of Education, 28, 431-450.

Carlise, L.R., Jackson, B.W. \& George, A. (2006). Principles of social justice education: The social justice education in schools project. Equity and Excellence in Education, 39:55-64. 
Conrad, C. F. \& Serlin, R. C. (2006). The SAGE Handbook for Research in Education: Engaging Ideas and Enriching Enquiry. Thousand Oaks: SAGE.

Creswell, J.W. (2007). Qualitative inquiry and research design: choosing among five approaches. (2nd ed.). Thousand Oaks, CA: SAGE.

Crocker, D.A. (2004). Tolerance and deliberative democracy. Paper presented at the: $4^{\text {th }}$ Conference of the Human Development and Capacity Association, 5 - 7 September 2004, Pavia, Italy.

Crozier, G. (2000). Parents and schools: Partners or protagonists? Stoke-on-Trent: Trentham Books.

Department of Education, 1996. Education White Paper 2. The organisation, governance and funding of schools. Pretoria: Government Printer.

Everett, G. (1998). The impact of site-based decision-making on student achievement as measured by The TAAS. Unpublished doctoral dissertation. Texas A \& M University-Kingsville and Corpus Christi.

Gibson, J.L. \& Gouws, A. (2003). Overcoming intolerance in South Africa. Cambridge: Cambridge University.

Grant, T. (2007). Transformation challenges in a South African workplace. Business Communication Quarterly, March, 71 (3), 380 - 383.

Grant-Lewis, S \& Naidoo, J. (2004). Whose theory of participation? School Governance in South Africa. Current Issues in Comparative Education, 6(2), 100-112.

Gray GE, van Niekerk R, Struthers H, Violari A, Matison N, McIntyre J \& V Naidoo 2006. The effects of adult morbidity and mortality on household welfare and wellbeing of children of Soweto. Vulnerable Children and Youth Studies, 1(1):15-28.

Gutmann, A. (1996). Democracy and its discontents. In: A. Sarat \& D.R. Villa (Eds) 1996. Liberal modernism and democratic individuality. Princeton: Princeton University.

Harber, C. (2004). Schooling as violence. London: Routledge Falmer.

Harber, C. (1995). Democratic Education and the international agenda. In: Harber C (ed). 1995. Developing democratic education. Tiknall. Education Now Books.

Heystek, J. (2004). School Governing Bodies-the principal's burden or the light of his or her life? South African Journal of Education, 24(4), 308-312.

Hoy, WK \& Tarter, CJ 2004. Organisational justice in schools: no justice without trust. International Journal of Educational Management, 18 (4), 250-259.

Hytten, K. (2006). Education for social justice: Provocations and challenges. Educational Theory, 56(2), 221-236.

Jansen, J.D. (2004). Race and education after ten years. Perspectives in Education, 22(4), 117-128.

Johnson, P. \& Scollay, S. (2001). School-based decision-making councils-conflict, leader power and social influence in the vertical team. Journal of Educational Administration, 39, 47-60.

Karlsson, J. (2002). The role of democratic governing bodies in South African schools. Comparative Education, 38, $327-336$.

Mabovula, N. (2009). Giving voice to the voiceless through deliberative democratic school governance. South African Journal of Education, 29, 219-233.

Mafora, P. (2012). Shared decision-making in school governance: A case study of two Soweto secondary schools. The International Journal of Learning. 18(6), 97-107.

Mafora, P. (2000). The implementation of shared decision-making in teacher training college management. Unpublished DEd thesis. Aucklandpark: Rand Afrikaans University.

MacGillivray, E.D \& Golden, D. (2007). Global diversity: Managing and leveraging diversity in a global workforce. International HR Journal, Summer 2007, 38-46.

Magadla, M. (2007). The role of the learner in the School Governing Body: Perceptions and experiences of principals, educators, parents and learners. Unpublished MEd dissertation. Edgewood. University of KwaZulu-Natal.

Mahlangu, R. (2008). The effective functioning of a School Governing Body: A case study in selected schools. Unpublished MEd dissertation. University of South Africa.

Mangena, M. (2012). Demobilised educational parenting. AZAPO e reng? 2012, March 06.

McMillan, J.H. \& Schumacher, S.S. (2006). Research in education: Evidence-based inquiry, (6 th ed). Boston: Pearson.

Ministerial Review Committee, (2004). Review of school governance in South African public schools: Report of the Ministerial Review Committee on school governance. Pretoria: Department of Education.

Mncube, V.S. (2009). Perceptions of parents of their role in the democratic governance of schools in South Africa: Are they on board? South African Journal of Education, 29, 83-103.

Mncube, V.S., Harber, C. \& du Plessis, P. (2011). Effective school governing bodies: Parental involvement, training and issues of school effectiveness in two provinces of South Africa. Acta Academica, 43(2), 54-81.

Mokonyane, N. (2011). Address by the Premier, at the Soweto Education Summit, Johannesburg, 09 April 2011. [Online] Available: http://www.polity.org.za/article/gp-mokonyane (March 3, 2012).

Ndlazi, S.M. (1999). An investigation of parental non-involvement of a Duncan Village school and its implications for the management of the school: A case study. Grahamstown: Rhodes University.

Ntshele, F.C. (2004). An evaluative study of the role of the school governing body parent component in decision making. Unpublished MEd dissertation. University of Zululand.

Parker, K. \& Leithwood, K. (2000). School councils' influence on school and classroom practice. Peabody Journal of Education, 75(4), 37-65.

Paul, E.F., Miller, F.D. \& Paul, F. (2000). Democracy. Cambridge: Cambridge University Press.

Republic of South Africa, (1996). Act No 84, South African Schools Act. Pretoria: Government Printer. 
Rukambe, J. (2009). Promoting political tolerance: Experiences from selected countries. A presentation to the 2009 Namibian Electoral Symposium, NAMPOWER Convention Centre, Windhoek 17-18 March.

Saunders, M., Lewis, P. \& Thornhill, A. (2000). Research methods for business students, $2^{\text {nd }}$ edition, Essex: Pearson Education.

Shields, C.M. (2004). Dialogic leadership for social justice: Overcoming pathologies of silence. Educational Administration Quarterly, 40(1), $49-54$.

Shumane, L.S. (2009). An evaluation of the role of parents in school governing bodies: A case study of selected rural public schools in the Butterworth District. Unpublished MPA dissertation. Port Elizabeth: Nelson Mandela Metropolitan University.

Smit, M.H. \& Oosthuizen, J. (2011). Improving school governance through participative democracy and the law. South African Journal of Education, 31, 55-73.

Smith, S.R. (2011). Equality and diversity: value incommensurability and the politics of recognition. Boston: The Polity Press.

Stetson, B \& Conti, J.G. (2005). The truth about tolerance: Pluralism, diversity and the cultural wars. Intervarsity Press.

Thomas, D.A. \& Ely, R.J. (2005). Making differences matter: A new paradigm for managing diversity. [online] http.hbr. harvardbusiness,org/1996/ making-differences-matter/ar/1 Accessed on 20 May 2012.

UNESCO, (1995). Declaration of Principles on Tolerance. [Online] http://www.unesco.org/cpp. Accessed on, 21 March 2012.

Valentine, S. \& Fleischman, G. (2002). Ethics codes and professionals' tolerance of societal diversity. Journal of Business Ethics, 40,301-312.

Van Wyk, N. (2007). The rights and roles of parents on school governing bodies in South Africa. International Journal about parents in Education, 1(0),132-139.

Van Wyk, N. (2004). School governing Bodies: The experiences of South African Educators. South African Journal of Education, 24(1),49-54.

Waghid, Y. (2002). In need of deliberative inter-school relations in the Northern Cape. South African Journal of Education, 22 (2), $95-$ 100.

Zajda, J. Majhanovich, S \& Rust, V. (2006). Education and social justice. Review of Education. 52, 9-22. 
